\title{
Training and Development, A Vital Tool For Organizational Effectiveness. (A Case Study of Sterling Bank Nigeria Plc)
}

\author{
Olusanya, Samuel Olumuyiwa ${ }^{1}$, Awotungase, Suleiman Adelaja ${ }^{2}$, Ohadebere \\ Emmanuel Chukwuemeka ${ }^{3}$ \\ ${ }^{1}$ Lecturer Lagos State University External system,ECONOMICS DEPARTMENT. \\ ${ }^{2}$ Lecturer Lagos State University External system BUSINESS ADMINISTRATION DEPARTMENT \\ Associate Lecturer Saint Augustines' College of Education Akoka \\ ${ }^{3}$ Lecturer Lagos State University External system BANKING AND FINANCE DEPARTMENT
}

\begin{abstract}
The research study takes a look at Training and Development, a vital tool for Organizational Effectiveness (a Case Study of Sterling Bank Nigeria Plc). However, the study make use of primary data and questionnaire were distributed to one hundred Staff of Sterling bank Nigeria Plc and Spearman's rank Correlation coefficient was adopted as the estimation techniques. More over, the objectives of the study examine the impact of staff training and development on Organizational Effectiveness and to also examine whether through Staff training and development of employees in Sterling bank Nigeria Plc, the bank's performance has been enhanced. More over, the result of the study reveals that Staff Training and development has a significant effect on organizational effectiveness and that Staff Training and development has enhanced employees performance in Sterling bank Nigeria Plc. Therefore, the study recommend and conclude that the training and development is a vital tool to achieve organizational effectiveness in Sterling bank Nigeria Plc and management training, leadership skills, language and technical skills training, should be the interest of the management of Sterling bank Nigeria Plc.
\end{abstract}

Keywords: Training and Development, Motivation, technical skill, organizational Effectiveness, Sterling bank Nigeria Plc.

\section{Introduction}

Training both physically, socially, intellectually and mentally are very essential in facilitating not only the level of productivity but also the development of personnel in any organization. Therefore, training can be put in a contact relevant to school administrators. However, knowledge is the ability, the skill, the understanding, the information, which every individual requires acquiring in order to be able to function effectively and perform efficiently. Human resources, are the most valuable assets of any organization, with the machines, materials and even the money, nothing gets done without man-power. Abiodun (1999) submitted that: Training is a systematic development of the knowledge, skills and attitudes required by employees to perform adequately on a given task or job. It can take place in a number of ways, on the job or off the job; in the organization or outside organization. Adeniyi (1995) observed that staff training and development is a work activity that can make a very significant contribution to the overall effectiveness and profitability of an organization. He therefore, provides a systematic approach to training which encases the main elements of training. The effectiveness and success of an organization therefore lies on the people who form and work within the organization. It follows therefore that the employees in an organization to be able to perform their duties and make meaningful contributions to the success of the organizational goals need to acquire the relevant skills and knowledge. In appreciation of this fact, organization like educational institution, conduct final training and development programmes for the different levels of their manpower.

Usually, before training or development programmes are organized efforts are being made through individuals and organizational appraisals to identify the training needs. After the training and development programmes, an evaluation is carried out to ascertain the effectiveness of the programme in line with the need, which had been identified. It is worthy of mention that organization development follows the development of individual who form the organization. It follows that no organization becomes effective and efficient until the individual have and apply the required skills and knowledge.

Training has been observed as part of human development. Human development is a process of enlarging people's choices. In principle, these choices can be infinite and change over time. But at all levels of development, the three essential ones are for people to live a long and healthy life, to acquire knowledge through training, and to have access to resources needed for a decent standard of living. If these essential choices are not available many other opportunities remain inaccessible. 
According to the concept of human development income is clearly only one option that people would like to have, albeit an important one. Development must therefore be more than just the expansion of income and wealth. (HDR 1990) since administering involves the creation and maintenance of an environment for performance, working closely or in isolation towards the accomplishment of common goals, it is obvious that administrators cannot be successful without well skilled and well trained people. The importance of incorporating training into organizational or institutional roles the staffing of these roles and the entire process of direction and leading people must be premises on knowledge and skills. The need for improved productivity in organization has become universally accepted and that it depends on efficient and effective training. It has further become necessary in view of advancement in modern world to invest in training. Thus, the role played by staff training and development can no longer be over-emphasized. However, the need for organizations to embark on staff development programme for employees has become obvious. Absence of these programme often manifest tripartite problems of incompetence, inefficiency and ineffectiveness. Oribabor (2000) submitted that training and development aim at developing competences such as technical, human, conceptual and managerial for the furtherance of individual and organization growth, also Isyaku (2000) postulated that the process of training and development is a continuous one.

Man is dynamic in nature, the need to be current and relevant in all spheres of human endeavor's make staff development a necessity, to keep track with current event and methods. Griffin, (1978) Ajibade, (1993) Adeniyi, (1995) and Arikewuyo (1999) have drawn the attention of the entire sundry to the inestimable value of training and development. It is an avenue to acquire more and new knowledge and develop further the skills and techniques to function effectively. Scholars, experts, social scientist and school administrators now recognize the fact that training is obviously indispensable not only in the development of the individuals but also facilitate the productive capacity of the workers. Training is not coaxing or persuading people to do what is wanted but rather a process of creating organizational conditions that will cause personnel to strive for better performance. Among other schools that highlighted the usefulness of training are Akintayo (1996), Oguntimehin (2001) and Graig (1976). They identified the functions of training as follow: increase productivity, improves the quality of work; improves skills, knowledge, understanding and attitude; enhance the use of tools and machine; reduces waste, accidents, turnover, lateness, absenteeism and other overhead costs, eliminates obsolesce in skills, technologies, methods, products, capital management etc. It brings incumbents to that level of performance which needs the performance for the job; enhance the implementation of new policies and regulations; prepares people for achievement, improves man-power development and ensures the survival and growth of the enterprise. Pitfield (1982) is of the opinion that the objectives of training are to: provide the skills, knowledge and aptitudes necessary to undertake required job efficiently develop the workers so that if he has the potentials, he may progress, increase efficiency by reducing spoilt work, misuse of machines and lessening physical risks. Furthermore the failure of the management to provide reasonable compensation recognition and other incentives that nurtures and drives the employees emotionally, in the same vein, the management's failure to identify the training for those areas of skills and knowledge the employees' lack and changing technology and the inability of the organization to expose the employees in some cases, the employees do not possess the physical and mental capacity to apply the skills and knowledge and use the tools to meet the objectives of the position they occupy. Finally all the above mentioned problems have negative effects on the employee's performance of an organization. However, the objectives of the study is to examine the impact of staff training and development on Organizational Effectiveness, to also examine whether through Staff training and development of employees in Sterling bank Nigeria Plc, the bank's performance has been enhanced.

\section{Brief Literature Review}

As we know that training and development refers to the process to obtain or transfer KSA (knowledge, skills and abilities) needed to carry out a specific activity or task ; therefore, benefits of training and development both for employer and employees are strategic in nature and hence much broader. In order to meet the current and future challenges of our business, training and development assumes a wide range of learning actions, ranging from training of the employees for their present tasks and more so, knowledge sharing to improve the business horizon and customer's service. It also focuses on their career development, thus expanding individual, group and organizational effectiveness. A comprehensive training and development program helps in deliberating on the knowledge, skills and attitudes necessary to achieve organizational goals and also to create competitive advantage (Peteraf 1993). In fact, in the start of the twenty-first century Human Resource Managers have opined that one of the main challenges they are to confront had involved issues related to training and development (Stavrou, Brewster and Charalambous 2004).

In order to ensure that our employees are equipped with the right kind of skills, knowledge and abilities to perform their assigned tasks, training and development plays its crucial role towards the growth and success of our business. By choosing the right type of training, we ensure that our employees possess the right skills for our business, and the same need to be continuously updated in the follow up of the best and new HR practices. 
To meet current and future business demands, training and development process has assumed its strategic role and in this regard few studies by Stavrou et al.'s (2004) and Apospori, Nikandrou, Brewster and Papalexandris's (2008), have attained much importance as these highlight the T\&D practices in cross-national contexts. Apospori et al. (2008) had deduced that there is a considerable impact of training on organizational performance. Differently from these studies, Cunha, Morgado and Brewster (2003) were the only ones who could not determine the impact of training on organizational performance, and suggested that another study on analysis of this relationship was needed.

Jackson (2002) opined that some cultural assumptions underlie human resource management with regards to developing employees: he deliberated through an example which highlighted the distinction between the hard and soft approaches on developmental aspects, appearing in the strategic HRM literature. The hard approach assumed the employees in the organizations as mere resources to achieve the objectives of the organization, where as the soft approach viewed the employees more as valued assets capable of development (Tyson and Fell 1986; Hendry and Pettigrew 1990).The need for developing our employees is compelling because a sound Training and Development plan has its contributions to increase productivity and quality of work. The development strategy reduces staff turnover and absenteeism and also helps in improving motivation among the employees. In order to stay ahead of our competition, training and development plan must incorporate innovation and reinvention and this is only possible when training encompasses a wide range of learning actions. Therefore, an ideal training shall become part of a company-wide strategy and it must be is linked to business goals and organizational performance.

\section{Reactive Approach \\ III. Approaches To Training And Development}

The traditional approaches to training can be generally termed as reactionary, driven by tactical delivery of technical skills in bricks and mortar, classrooms trainings and where training is seen as an event oriented activity.

\section{Proactive Approach}

In the learning organization this approach aligns all learning activities with the corporate business strategy, and its focus is on developing competencies.

\section{Active Learning Approach}

In this approach, trainees play a leading role in learning by exploring issues and situational problems under the guidance of their facilitator. The trainees learn by asking thought provoking questions, searching for answers, and interpreting various observations made during the process. The active learning approach has its lasting impact on learning since it helps in long-term retention and finding better solutions in the challenging situations. In today's fast paced world, continuous learning is essential to success. Individuals need to learn to succeed in life and at work. Companies need to ensure their employees continue to learn, so they can keep up with increased job demands and so the company can gain or maintain competitive advantage.

Training and development otherwise known as manpower training and development, human resources training and development, employees training and development or simply as training and development has been given great attention in the recent times this is because of the fact that of all factors of production man seems to be the only factor that has to be refined through training and development to get the best out of it. Thus, training and development is very essential in an industry because employees make things happen efficiently. Efforts will therefore be made to review relevant literatures on the concept of training and development, types, training and development and organizational productivity etc.

\section{The Concept Of Training And Development}

Training and development has been given various definitions by various authors. In fact there seems to be no definition that can stand on its own as every definition seems to complement one another. According to Nwachukwu (1958) Training is organizational efforts aimed at helping an employee to acquire basic skills required for the efficient execution of the functions for which he was hired, while development deals with the activities undertaken to expose an employee to perform additional duties and assume positions of importance in the organizational hierarchy. Williams (1963) says trainees are for the future force rather than for today and so more element of manpower forecasting is inevitable if the manpower training and forecasting is to be successful. Ubeku (1975) defined management training as the process of developing managers knowledge, skills and attitudes through instruction, demonstration, practice and planned experience to meet the present and future needs of the organization. He opines that training is a continuous process in any organization. 
Boctomley (1983) drew a distinction between training and development. He defined training as the acquisition of knowledge and skills and that development concerns changes in attitudes and behavior.

John (1983) defined training as that process which attempts to fill the gap between what an employee has to offer by way an employee has to offer of accumulated skill, experience and aptitudes and that which is demanded by the job.

Cowlen (1990) corroborates the above definitions of training and development when he defined training as the systematic development of the attitude knowledge and skill behavior pattern required by an individual in order to perform adequately a given task or job and opines that development represents one of the most important activities in an organization which might even be said to be the most important activity because the success of an industry is directly affected by the caliber of its management. Cascio (1991) says training activities are planned programs of organizational improvement undertaken to bring about a relatively permanent change in employees knowledge (e.g. familiarity with all the items in a particular product line). Skills (e.g. ability to deal diplomatically with customers, attitudes (e.g.satisfaction with training which leads the employees to seek out further training) or behavior (e.g.acceptable performance of the job for which training was provided).

According to Ghartey (1993) "Training is expected to supplement education by developing or augmenting the knowledge skills, and attitudes a person has acquired from education with a view to enabling the person to apply them in specific work orpractical situations.

Beach (1995) defined training as the organized procedure by which people learn knowledge and/or skills for a definite purpose. He said the objective of training is to achieve a change in the behaviour of those trained in the industrial situation this means that the trainees shall acquire new manipulative skills, technical knowledge, problem solving ability or employees apply their newly acquired knowledge and skills on the job in such a way so as to aid in the achievement of organizational goals.

Mckenna and Beech (1995) regard training and development as interactive, each complementing the other. According to them, training as a vehicle for human resource development is concerned with improving the skills of employees and enhancing their capacity to cope with the ever changing demands of the work situation which could also make a positive contribution to the empowerment of employees on the other hand, management development is an activity that sets out to ensure that the organization has the present and future with confidence.

However, Kamoche (1997) reminds us: The human resources refers to the accumulated stock of knowledge, skill and abilities that the individual possess, which the firm has build up overtime into an identifiable expertise through training and development of its employees. If human resources management is to fulfill its aim of valuing human "assets", it is necessary to invest in them. This implies a positive attitude towards training and development.

In addition, Fanibuyan (2001) defines training as the systematic process of altering the behaviour and or attitudes of employees in a direction to increase organizational goals and development as programme generally aimed at educating supervisory employees above and beyond the immediate technical requirement of the job and have a main objective of the improvement of the effective performance of all managers. These development programmes are intended to train the employees in the use of skills. Katz (1955) classified such skills into three:

(i) Technical Skill

(ii) Conceptual Skill and

(iii) Human Skill.

Going by the various perspectives on training and development, one can concisely say that training has to do with the altering of behavior, knowledge, and /or motivation of employees in a direction to increase organizational goal accomplishment while development means the advancement in ones experience, skills and attitudes to become or remain successful leaders in organizations.

\section{Methodology}

This research study will basically make use of primary data that would be used in generating questionnaire which will be administered to the Staff of Sterling bank Nigeria Plc Head Office, Lagos. However, the study population comprises 100 Staff of Sterling bank Nigeria Plc across the department at the head office.

However, Spearman's rank correlation coefficient will be adopted in this study and it is also appropriate to use Spearman's correlation when both variables are'continuous and the formular is as follows; $\mathrm{R}=1-\frac{6 \sum \mathrm{d}^{2}}{\mathrm{n}\left(\mathrm{n}^{2}-1\right)}$ 
Where $\quad d=$ the difference between the ranks of each pair.

$\mathrm{n}=$ number of paired observations

\begin{tabular}{|l|l|}
\hline Correlation Range & Strength of Association \\
\hline \pm 0.70 to $\pm \mathbf{1 . 0 0}$ & Strong \\
\hline$\pm \mathbf{0 . 4 0}$ to $\pm \mathbf{0 . 6 9}$ & Moderate \\
\hline$\pm \mathbf{0 . 2 5}$ to $\pm \mathbf{0 . 3 9}$ & Weak \\
\hline$\pm \mathbf{0 . 1 0}$ to $\pm \mathbf{0 . 2 4}$ & Very Weak \\
\hline$\pm \mathbf{0 . 0 0}$ to $\pm \mathbf{0 . 0 9}$ & None \\
\hline
\end{tabular}

Source: Nyang, (2005).

\section{Research Hypotheses}

Null Hypothesis (Ho): Staff Training and development has no significant effect on Organizational effectiveness.

Alternative Hypothesis (H1): Staff Training and development has a significant effect on organizational effectiveness.

\section{RESEARCH HYPOTHESIS 2}

Null Hypothesis (Ho): Staff Training and development has not enhanced employees performance in Sterling bank Nigeria Plc.

Alternative Hypothesis (Hi): Staff Training and development has enhanced employees performance in Sterling bank Nigeria Plc.

\section{ANALYSIS}

Table 1 SEX DISTRIBUTION

\begin{tabular}{|l|l|l|l|}
\hline RESPONSES & FREQUENCY & \% & CF \\
\hline Male & $\mathbf{7 6}$ & $\mathbf{7 6}$ & $\mathbf{7 6 . 0}$ \\
\hline Female & $\mathbf{2 4}$ & $\mathbf{2 4}$ & $\mathbf{1 0 0 . 0}$ \\
\hline Total & $\mathbf{1 0 0}$ & $\mathbf{1 0 0}$ & \\
\hline
\end{tabular}

Source: Field Survey 2012

The result above shows that 76 out of 100 respondents are male and this gives $76 \%$ of the whole respondents while 24 out of 100 respondents are female and this constitutes $24 \%$ of the total respondent. We can then conclude that there are more male than female respondents in the research study.

Table 2 MARITAL STATUS DISTRIBUTION

\begin{tabular}{|l|l|l|l|}
\hline RESPONSES & FREQUENCY & \% & CF \\
\hline Single & 28 & $\mathbf{2 8}$ & $\mathbf{2 8 . 0}$ \\
\hline Married & $\mathbf{5 2}$ & $\mathbf{5 2}$ & $\mathbf{8 0 . 0}$ \\
\hline Divorced & $\mathbf{2 0}$ & $\mathbf{2 0}$ & $\mathbf{1 0 0 . 0}$ \\
\hline Total & $\mathbf{1 0 0}$ & $\mathbf{1 0 0}$ & \\
\hline
\end{tabular}

Source: Field survey 2012

The table 2 above shows that 28 out of 100 respondents are single and it gives $28 \% .4$ of the total respondents, 52 out of 100 respondents is married and this gives $52 \%$ of the whole respondents while 20 out of 100 respondents are divorced and this represent $20 \%$ of the total respondents. Therefore we can then conclude from the analysis that there are more married than single respondents in the research study.

Table 3 AGE DISTRIBUTION

\begin{tabular}{|l|l|l|l|}
\hline RESPONSES & FREQUENCY & $\%$ & CF \\
\hline Below 25 years & 24 & 24 & $\mathbf{2 4 . 0}$ \\
\hline Between 25-35 years & 62 & 62 & $\mathbf{8 6 . 0}$ \\
\hline Between 36-45 years & 12 & 12 & 98.0 \\
\hline 46 and above & 2 & 2 & 100.0 \\
\hline Total & 100 & 100 & \\
\hline
\end{tabular}

Source: Field survey 2012 
The result above reveals that 24 out of 100 respondents are below 25 years and this represent $24 \%$ of the whole respondents, 62 out of 100 respondents are between the age 25-35 years and this constitutes $62 \%$ of the total respondents 12 out of 100 respondents are between the age 36-45 years and this represent $12 \%$ of the total respondents while only two respondent is 46 years and above and this gives $2 \%$.

Therefore, we can then conclude that there are more respondents between the ages 25-35 years in the research study.

Table 4 EDUCATIONAL QUALIFICATION DISTRIBUTION

\begin{tabular}{|l|l|l|l|}
\hline RESPONSES & FREOUENCY & $\%$ & CF \\
\hline WAEC & 4 & 4 & 4.0 \\
\hline NCE/OND & 30 & 30 & 34.0 \\
\hline HND/B.SC & 44 & 44 & $\mathbf{7 8 . 0}$ \\
\hline M.Sc./MBA & 22 & 22 & 100.0 \\
\hline Total & 100 & 100 & \\
\hline
\end{tabular}

Source: Field survey 2012

The result above reveals that 4 respondents have WAEC qualification and this gives $4 \%$ of whole respondents, 30 respondents have NCE/OND qualification and this gives $30 \%$ of the total respondents. However, 44 respondents have HND/BSC qualification and this represent $44 \%$ if the whole respondents while 22 respondents have MSC/MBA qualification and it give $22 \%$ of the total respondents. Therefore, we can then conclude that respondents that have HND /BSC qualification are more in the research study.

RESULT OF GENERAL QUESTIONS DISTRIBUTED TO THE RESPONDENTS

\begin{tabular}{|c|c|c|c|c|}
\hline 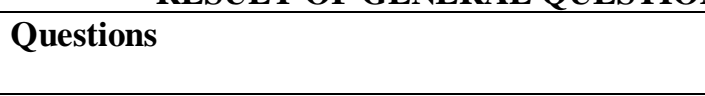 & Response & Frequency & $\begin{array}{l}\text { Cumulative } \\
\text { Frequency }\end{array}$ & $\begin{array}{l}\text { Percentage } \\
(\%)\end{array}$ \\
\hline $\begin{array}{l}\text { 1. Your bank gives cognance to training and } \\
\text { development programme. }\end{array}$ & $\begin{array}{l}\text { COLUMN } \\
\text { SA } \\
\text { A } \\
\text { SD } \\
\text { D }\end{array}$ & $\begin{array}{l}80 \\
20 \\
- \\
-\end{array}$ & $\begin{array}{c}80.0 \\
100.0\end{array}$ & $\begin{array}{l}80 \% \\
20 \%\end{array}$ \\
\hline $\begin{array}{l}\text { 2. Members of staff are usually sent for } \\
\text { training and development programme. }\end{array}$ & $\begin{array}{l}\text { SA } \\
\text { A } \\
\text { SD } \\
\text { D }\end{array}$ & $\begin{array}{l}100 \\
- \\
- \\
-\end{array}$ & 100 & $100 \%$ \\
\hline $\begin{array}{l}\text { 3. The training method adopted in your bank } \\
\text { are on-the-job and off-the-job training. }\end{array}$ & $\begin{array}{l}\text { SA } \\
\text { A } \\
\text { SD } \\
\text { D } \\
\end{array}$ & $\begin{array}{l}\mathbf{7 0} \\
30 \\
- \\
- \\
\end{array}$ & $\begin{array}{r}70.0 \\
100.0\end{array}$ & $\begin{array}{l}\mathbf{7 0 \%} \\
\mathbf{3 0 \%}\end{array}$ \\
\hline $\begin{array}{l}\text { 4.The training programme are usually } \\
\text { relevant to Your job performance. }\end{array}$ & $\begin{array}{l}\text { SA } \\
\text { A } \\
\text { SD } \\
\text { D } \\
\end{array}$ & $\begin{array}{l}100 \\
- \\
- \\
- \\
\end{array}$ & 100.0 & $100 \%$ \\
\hline $\begin{array}{l}\text { 5. The training conditions are adequate } \\
\text { enough for trainees to be able to benefit } \\
\text { from the programme. }\end{array}$ & $\begin{array}{l}\text { SA } \\
\text { A } \\
\text { SD } \\
\text { D } \\
\end{array}$ & $\begin{array}{l}55 \\
45 \\
- \\
- \\
\end{array}$ & $\begin{array}{r}55.0 \\
100.0\end{array}$ & $\begin{array}{l}55 \% \\
45 \%\end{array}$ \\
\hline $\begin{array}{l}\text { 6. The training programme are usually } \\
\text { conducted for all cadre of staff. }\end{array}$ & $\begin{array}{l}\text { SA } \\
\text { A } \\
\text { SD } \\
\text { D }\end{array}$ & $\begin{array}{l}60 \\
20 \\
- \\
20\end{array}$ & $\begin{array}{r}60.0 \\
80.0 \\
100.0\end{array}$ & $\begin{array}{l}60 \% \\
20 \% \\
\\
20 \%\end{array}$ \\
\hline $\begin{array}{l}\text { 7. Your bank output is equally maximized as } \\
\text { a result of staff improved performance. }\end{array}$ & $\begin{array}{l}\text { SA } \\
\text { A } \\
\text { SD } \\
\text { D } \\
\end{array}$ & $\begin{array}{l}100 \\
- \\
- \\
- \\
\end{array}$ & 100.0 & $100 \%$ \\
\hline $\begin{array}{l}\text { 8. Staff training has a direct relationship with } \\
\text { output maximization of your bank. }\end{array}$ & $\begin{array}{l}\text { SA } \\
\text { A } \\
\text { SD }\end{array}$ & $\begin{array}{l}\mathbf{5 0} \\
\mathbf{5 0} \\
-\end{array}$ & $\begin{array}{r}50.0 \\
100.0\end{array}$ & $\begin{array}{r}50 \% \\
100 \%\end{array}$ \\
\hline
\end{tabular}




\begin{tabular}{|c|c|c|c|c|}
\hline & D & - & & \\
\hline $\begin{array}{l}\text { 9. There is significant relationship between } \\
\text { training and development and employees } \\
\text { performance in your bank. }\end{array}$ & $\begin{array}{l}\text { SA } \\
\text { A } \\
\text { SD } \\
\text { D }\end{array}$ & $\begin{array}{l}100 \\
- \\
- \\
-\end{array}$ & 100.0 & $100 \%$ \\
\hline $\begin{array}{l}\text { 10. Training programme have strongly } \\
\text { influence on the effectiveness and efficiency of } \\
\text { Staff in Sterling bank. }\end{array}$ & $\begin{array}{l}\text { SA } \\
\text { A } \\
\text { SD } \\
\text { D }\end{array}$ & $\begin{array}{r}\mathbf{6 0} \\
33 \\
7 \\
-\end{array}$ & $\begin{array}{r}60.0 \\
83.0 \\
100.0\end{array}$ & $\begin{array}{r}\mathbf{6 0 \%} \\
33 \% \\
7 \%\end{array}$ \\
\hline $\begin{array}{l}\text { 11. Training and development has an } \\
\text { impact on the overall performance of the } \\
\text { Staff in Sterling bank. }\end{array}$ & $\begin{array}{l}\text { SA } \\
\text { A } \\
\text { SD } \\
\text { D }\end{array}$ & 100 & 100.0 & $100 \%$ \\
\hline $\begin{array}{l}\text { 12. Training and development of Staff has } \\
\text { improved bank's performance to a large } \\
\text { extent. }\end{array}$ & $\begin{array}{l}\text { SA } \\
\text { A } \\
\text { SD } \\
\text { D }\end{array}$ & $\begin{array}{c}70 \\
30 \\
- \\
-\end{array}$ & $\begin{array}{r}70.0 \\
100.0\end{array}$ & $\begin{array}{c}\mathbf{7 0 \%} \\
\mathbf{3 0 \%}\end{array}$ \\
\hline $\begin{array}{l}\text { 13. Investment in Training and Development } \\
\text { of Staff in Sterling bank is one of the key to } \\
\text { the success of the bank. }\end{array}$ & $\begin{array}{l}\text { SA } \\
\text { A } \\
\text { SD } \\
\text { D } \\
\end{array}$ & $\begin{array}{l}100 \\
- \\
- \\
- \\
\end{array}$ & 100.0 & $100 \%$ \\
\hline $\begin{array}{l}\text { 14. The level of training and development } \\
\text { received by Sterling bank Staff is } \\
\text { appropriate. }\end{array}$ & $\begin{array}{l}\text { SA } \\
\text { A } \\
\text { SD } \\
\text { D } \\
\end{array}$ & $\begin{array}{l}60 \\
40 \\
- \\
- \\
\end{array}$ & $\begin{array}{r}60.0 \\
100.0\end{array}$ & $\begin{array}{l}60 \% \\
40 \%\end{array}$ \\
\hline $\begin{array}{l}\text { 15.Through Training and Development, } \\
\text { Sterling bank has improved in terms of } \\
\text { Profitability and Deposit. }\end{array}$ & $\begin{array}{l}\text { SA } \\
\text { A } \\
\text { SD } \\
\text { D } \\
\end{array}$ & $\begin{array}{l}\mathbf{5 8} \\
22 \\
20\end{array}$ & $\begin{array}{r}58.0 \\
80.0 \\
100.0\end{array}$ & $\begin{array}{l}\mathbf{5 8 \%} \\
\mathbf{2 2 \%} \\
\mathbf{2 0 \%}\end{array}$ \\
\hline Total & & 100 & & 100.0 \\
\hline
\end{tabular}

Source: Field survey 2012

Where SA- Strongly Agree, A- Agree, SD- Strongly Disagree, D- Disagree.

Result of Spearman's Rank Correlation Coefficient For Research Hypothesis I And II

\begin{tabular}{|l|l|l|l|l|}
\hline & Q1 & Q9 & Q1 & Q9 \\
\hline $\begin{array}{l}\text { Spearman's rho Q1 } \\
\begin{array}{l}\text { Correlation Coefficient Sig. } \\
\text { (2-tailed) } \\
\text { N }\end{array}\end{array}$ & 1.000 & $.775^{* *}$ & 1.000 & $.766^{* *}$ \\
\hline $\begin{array}{l}\text { Q9 Correlation C } \\
\text { N }\end{array}$ & $\begin{array}{l}100 \\
100\end{array}$ & 100 & 100 & 100 \\
\hline
\end{tabular}

Source: SPSS Package

Decision Rule: If the Spearman's rank correlation H calculated is greater than Spearman's rank correlation H tabulated, we accept the alternative hypothesis and reject the null hypothesis. The tabulated value use here is $5 \%$ level of significance that is $* * \mathrm{P}<0.05$ and vice versa. However, it was revealed from the result above that the spearman's rank correlation coefficient results for research hypothesis one, and two values is given as 0.775 which established that there is a positive and strong relationships while 0.766 which established that there is a positive and strong relationships. More over, since the spearman's rank correlation coefficient calculated value 0.775 and is greater than Spearman's rank correlation coefficient tabulated value using 5\% level of significance $* * \mathrm{P}<0.05$ we then accept alternative hypothesis in hypothesis one and reject the null hypothesis, then conclude that Staff Training and development has a significant effect on organizational effectiveness. More over, since the spearman's rank correlation coefficient calculated value 0.766 is greater than spearman's rank correlation coefficient tabulated value using $5 \%$ level of significance $* * \mathrm{P}<0.05$, we then accept the alternative hypothesis and reject the null hypothesis, then conclude that Staff Training and development has enhanced employees performance in Sterling bank Nigeria Plc. 


\section{Recommendations And Conclusion \\ RECOMMENDATIONS}

It is an undeniable fact that in recent times many organizations have come to the realization of the importance of the role of training and development programs as it increases the organization's staff efficiency, skills and productivity. In order to reap the full benefits of a training initiative, Sterling bank should ensure that they Identify where training needed and it should be done more professionally in conjunction with the line manager as well as the individuals involved together with the HR personnel. Everyone involved should agree exactly to what the trainees are lacking, for instance what skill is needed, and what attitudes need to be changed toward work performance.

However, Objectives should be SMART (Specific, Measurable, Achievable, Realistic and Timely) and unambiguous, and should develop individual as well as meet the needs of the bank and Performance appraisal information system which is used yearly at the management level to assess employees' performance should provide specific information to employees about their performance problems and ways they can improve their performance.

However, the assessment should provide a clear understanding of the differences between current and expected performance, identifying the causes of the performance discrepancies and develop action plans to improve performance of employees through training and development programs.

More so, training needs should be considered on the basis of overall bank objectives. The goals of the bank should determine what training programs are to be organized for staff. Staff should be motivated to add value to themselves and to their lives. More so, organizational career planning involves matching an individual's career aspirations with the opportunities available in the organization. Career pathing is the sequencing of the specific jobs that are associated with these opportunities. For career management to be successful in Sterling bank Nigeria Plc, both the Management and Staff must assume equal share of the responsibility for it. The Staff must identify their aspirations and abilities, and through counseling recognize what training and development are required for a particular career information and training to its Staffs. Development and succession planning will also play a great role. Career progressions projection plans and training and development projections should be made available to each Staff.

Further more, Sterling bank could develop its Staff through formal education which will give employees the opportunity to attend short courses offered by consultants or an executive MBA and university programs which normally involve lectures by experts, business games and simulations, adventure learning and meetings with customers. More so, Motivation generally seeks to boost employees' morale to work hard and thus increase productivity. It is against this fact that the researcher wishes to recommend that in instituting proper training and development programs, Sterling bank Nigeria Plc should initiate a policy for motivation attached to training. Motivation include both extrinsic, such as more pay, allowance, fringe benefits, and intrinsic such as recognition, appreciation, acceptance by fellow workers, opportunities for promotion, career development and consultation for important matters.

Morale on the other hand increases productivity indirectly by reducing absenteeism, accidents, employee turnover and grievances. This means that the workforce can never develop in an organization where there is low morale and lack of motivation because motivation and morale leads to job satisfaction, which in turn leads to development.

More over, it is vital to evaluate training in order to assess its effectiveness in producing the learning outcomes specified when the training intervention is planned, and to indicate where improvements or changes are required to make the training even more effective. The basis upon which each category of training is to be evaluated should be determined at the planning stage while considering how the information required to evaluate learning events would be obtained and analyzed.

\section{Conclusion}

To be a key value creator by anticipating future business trends and delivering learning and employee development solutions for business success". It's a vision that translates into a relationship management approach to identify and meet the training needs of the key business areas. Specific product and skills training should the uppermost priority of Sterling bank to provide professionals training and development for its staffs in other to remain at the fore front of banking activities in Nigeria. Additionally, management training, leadership skills, language and technical skills training, should be the interest of the management of Sterling bank Nigeria Plc. Classroom-based training was also seen as one of the secret behind good performance in Sterling bank and it is paramount for any organization to employ technology to distribute learning solutions and information quickly, either by multimedia-based e-learning channels or CD-Rom/DVD.However, professional and comprehensive training resources are a significant benefit of joining the world's local bank, therefore any bank that need to succeed and progress need to provide facilities and resources for their Staff to access, in order to meet their learning needs and self-development goals. In conclusion, there are Learning opportunities in Sterling bank but it is up to the staffs to take them as they come. 


\section{References}

[1] Adamu S.O \& Johnson T L. (1997) Statistics for beginners book, SAAL publication, 36 Awolowo Avenue, Bodija, Ibadan

[2] Abiodun, E.J.A. (1999) Human Resources management, an overview.Concept Publication, Shomolu, Lagos. P. $110-121$.

[3] Adeniyi, O.I. (1995) "Staff training and development" in Ejiogu, A; Achumba, I. Asika (eds). Reading in Organizational Behaviour in Nigeria, Lagos. Maltho use Press Ltd, P. 159-167

[4] Achumba, H.C and Osuagwu, L. (1994) Marketing Fundamental and Practice Doby drive, Rock Hill, USA.

[5] Agiguo C.O. (1999) Business Research Methodology School of Business Administration, Abia State University.

[6] Argyris C (1971) The Management of Learning, 3rd edition Magraw-hall press, London.

[7] Ajibade, E.S. (1993) Staff development and in-service for teachers in Ajibade (Ed) Emia Nigerian Educational issues policies and practice in the eighties and Beyond. Publication, P.147-157.

[8] Akinpelu, B. (1999), Educational Technology and teaching - learning process in the 21st century in Adesomowo, P.O. (Ed), Basic of Education, Lagos Triumph Books publishers.

[9] Akintayo, M.O. (1996) Upgrading the teachers status through in-services training by Distant Learning System (DLS) Unpublished. A public lecturer at the Second convocation ceremony of NTI, NCE by DLS.

[10] Arikewuyo, M.O. (1999), Improving teachers' productivity in Nigeria, in Adesemowo P.O.(Ed). Basic of Education, Lagos Triumph Books Publishers, P. $102-109$.

[11] Apospori, E., Nikandrou, I., Brewster, C., and Papalexandris, N. (2008), 'HRM and Organizational Performance in Northern and Southern Europe,' International Journal of Human Resource Management 19, 7, 1187-1207.

[12] Aycan, Z. (2003), 'Human Resource Management in Cultural Context', paper presented at the 7th International Human Resource Management Conference Limerick, Ireland, June.

[13] Bass B.M. and Yaughan J.A (1969) Training Industry: The Management of Learning, Tavistock Publication, London.

[14] Betel, R.L (1968) What every supervisor should know, McGraw-hill Book Company London.

[15] Betts, P.W. (1989) Supervisory Studies: A Managerial Perspective, Pitman Publishing, 128, Long Acre, London W13E 9AN, Human Resources Present Personnel Manager Training Needs Assessment www.doi.gov.

[16] Becker, B.E., and Huselid, M.A. (1998), 'High Performance Work Systems and Firm Performance: A Synthesis of Research and Managerial Implications,' in Research in Personnel and Human Resource Management, ed. G.R. Ferris, Greenwich, CT: JAI Press, pp. 53-101.

[17] Blanchard, N.P., and Thacker, J.W. (1999), Effective Training: Systems, Strategies and Practices, Upper Saddle River, NJ: Prentice Hall. Cascio, W. (1991), Applied Psychology in

[18] Personnel Management (4th ed.), Upper Saddle River, NJ: Prentice Hall. Chris Obisi (1996) Personnel Management Jackbod Enterprises. Ojokondo Layout Agbowo, Ibadan.

[19] Cyphra R.K. (1989) Management of Human Resources, V.K. publishing house India

[20] Crouch, S. (1984) Marketing Research for Managers, William Heinemann Ltd, London W19PA.

[21] Cunha, R., Cunha, M., Morgado, A., and Brewster, C. (2003), 'Market Forces, Strategic Management, HRM Practices and Organizational Performance, A Model Based in a European Sample,' Management Research, 1, 1, 79-91.

[22] Dayal, R.K.(2000) Management Training in organization, Prentice-hall of India private limited New Delhi

[23] Daft, R. L. (1983) Organization Theory and Design, Minnesota, West Publishing Company. Delery, J.E., and Doty, H.D. (1996), 'Modes of Theorizing in Strategic Human Resource Management: Types of Universalistic, Contingency, and Configurational Performance Predictions,' Academy of Management Journal, 39, 4, 802-835.

[24] Encyclopaedia Britannica (1986) Mircopaedia (Ready reference and index) Vol.VII.

[25] Emeka E.O. (1999) Human Resource Management in perspective, Peterson Publications, Aba, Abia State.Frances and Roland S. (2003) Training Needs, Analysis and Evaluation, Chartered institute of Personnel Development, United Kingdom.

[26] French, W. L (1986) Human Resources Management, Houghton Mifflin Co., Boston.

[27] Fryer, D.H, Feinberg M.R and Zalkind S.S (1956) Developing People in Industry Hamper and Brothers, New York. Ferris, G.R., Hochwarter, W.A., Buckley, M.R., Harrell-Cook, G., and Fink, D.D. (1999), 'Human Resources Management: Some New Directions,' Journal of Management, 25, 3, 385-415.

[28] Fombrun, C., Tichy, N.M., and Devanna, M.A. (1984), Strategic Human Resource Management, New York: John Wiley.

[29] Heneman, H.G Schwab, Fossom D.P and Dyer, L.D. (1986) Personnel and Human Resources management, Irwin, Homewood, Illinois.ILO Publication, International Labor Office, CTF - 1211 Geneva 22, Switzerland.

[30] Hofstede, G. (2001), Culture's Consequences: Comparing Values, Behaviours, Institutions and Organizations across Nations, London: Sage.

[31] House, R.J., Hanges, P.J., Javidan, M., Dorfman, P.W., and Gupta, V. (2004), Culture, Leadership and Organizations, The GLOB E Study of 62 Societies, Thousand Oaks, CA: Sage.

[32] Isyaku, I.A. (2000) Training and retraining of Teachers through Distance Education.Being a paper presented at the National Workshop on Distance Education Held at Abuja Nigeria. 27-29

[33] Ignjatovic, M., and Svetlik, I. (2003), 'European HRM Clusters,' EBS Review, 17, 25-39. Jackson, T. (2002), 'The Management of People Across Cultures: Valuing People Differently,' Human Resource Management, 41, 455-475.

[34] Javidan, M. (2004), 'Performance Orientation,' in Culture, Leadership and Organizations, The GLOBE Study of 62 Societies, eds. R.J. House, P.J. Hanges, M.

[35] Javidan, P.W. Dorfman and V. Gupta, Thousand Oaks, CA: Sage, pp. 239-281. Kab M. (1976) Management Consulting: A guide to the Profession, ILO Publication, International Labour Office, CTF - 1211 Geneva 22, Switzerland.

[36] Kayode, Taiwo (2001) “ The Role of Training in charge Management" Journal of the Institute of Personnel Mangement of Nigeria. Vol. 10, No 7 P. $24-31$.

[37] KB ivy. (1976) Management Consulting: A guide to the Profession, 5th dition, BBL publication. Kellye Whitney (2004) Reducing Time to Proficiency in Global uman Resources Development. www.closourcebook.orq.

[38] Koonts H. 0' Daniel C \& Werhich(1980) Principle of Management, McGraw Hill London.

[39] Lyles, M., Baird, I., Orris, B., and Kuratko, D. (1993), 'Formalized Planning in Small Business Increasing Strategic Choices,' Journal of Small Business Management, 31, 2, 38-48.

[40] Loftus G.R. \&Loftus R.F (1982) Essence of Statistics Alfred A. Knop Inc. 201 East 50, street New York.

[41] Mathis, R.G, Jackson, J.N (1988) Personnel Human Resource Management, Tata McGraw New Delhi.

[42] Mcghee w.and $m$ Thayer P.w. (1961) Training in Business and Industry, John Willey, London.

[43] Mondy, R.W. et al (1990), Management and Organization Behavior. Boston, Allyn and Bacon Publishers. 
[44] Monnapa, A and Saiyanain M (1996) Personnel Management, lata McGraw hill publishing company limited New DeimnInternational Inc. London.

[45] Musselman V.A. Hughes E.H \& Jackson J.H (1981) Introduction to Modern Business: Issues and Environment Practice - Hall International, Inc. London.

[46] Musselman, V.A and Hughes E.H (1981) Introduction to Mordern Business, Practice Hall International Inc., London.

[47] Onasanya S.A. B (1999) Effective Personnel Management and Industrial relations, Management Village Shangisha, Lagos.

[48] Oguntimehin, A. (2001) "Teacher Effectiveness: Some practical Strategies for Successful implementation of Universal Basic Education in Nigeria" African Journal of Educational Management Vol. 9, No 1 P. 151 - 161.

[49] Oribabor, P.E. (2000), "Human Resources Management, A Strategic Approval,." Human Resources Management 9 (4) 21 - 24.

[50] Popoola (1999) Business Research Methods: An Andragogical Approach, University of Lagos Press, Akoka, Yaba-Lagos, Nigeria Peteraf, M.A. (1993), 'The Cornerstones of Competitive Advantage: A Resource-Based View,' Strategic Management Journal, 14, 3, 179-192.

[51] Poole, M., and Jenkins, G. (1996), 'Competitiveness and Human Resource Management Policies,' Journal of General Management, 22, 2, 1-19.

[52] Ronen, S., and Shenkar, O. (1985), 'Clustering Countries on Attitudinal Dimensions: A Review and Synthesis,' Academy of Management Review, 10, 435-455.

[53] Readership Institute (2002) High Impact of Management Practices, 4th edition, MJT Publication limited.Shinha A.D.(1974) With Management Development, ISTS survey of Indian business practice Calcutta, India.

[54] Seigie, M.R. (1972) Schaum's outline series: Theory and Problems of Statistics, Mac-hill publishing Co Ltd. Johannesburg.Stavrou, E., Brewster, C., and Charalambous, C. (2004), 'Human Resource Management as a Competitive Tool in Europe,' working paper, London: Henley College

[55] Tyson, S., and Fell, A. (1986), Evaluating the Personnel Function, London: Hutchinson. Youndt, M.A., Snell, S.A., Dean, J.W. Jr, and Lepak, D.P. (1996), 'Human Resource

[56] Management, Manufacturing Strategy, and Firm Performance,' The Academy of Management Journal, 39, 836-841. 